\title{
Anthrovision
}

Vaneasa Online Journal

$6.1 \mid 2018$

Film in Ethnographic Exhibitions

\section{Encountering Films in the Estonian National Museum}

\section{Karin Leivategija}

\section{(2) OpenEdition}

1 Journals

\section{Electronic version}

URL: http://journals.openedition.org/anthrovision/3390

DOI: 10.4000/anthrovision.3390

ISSN: 2198-6754

\section{Publisher}

VANEASA - Visual Anthropology Network of European Association of Social Anthropologists

\section{Electronic reference}

Karin Leivategija, "Encountering Films in the Estonian National Museum », Anthrovision [Online]

6.1 | 2018, Online since 31 December 2018, connection on 28 July 2019. URL : http://

journals.openedition.org/anthrovision/3390; DOI : 10.4000/anthrovision.3390

This text was automatically generated on 28 July 2019

(C) Anthrovision 


\title{
Encountering Films in the Estonian National Museum
}

\author{
Karin Leivategija
}

\section{Introduction}

1 The Estonian National Museum's (ENM) new building opened in October 2016 in the city of Tartu. It moved from its previous location in the city centre to a former Soviet military airfield, which is located in the border of the city. ${ }^{1}$ The aim of the new building was to establish a place of culture and memory, as well as one of contemporary society and social dialogue that offers representations of everyday life in Estonia from the Stone Age to the present. Instead of presenting undisputed knowledge and delivering monologues, the new building and exhibitions aim to provide a space for dialogue - to become a forum that is inclusive and encourages debate in contrast to a temple that is authoritative and beyond reproach (Delgado 2009: 8; Cameron 1971).

2 The ENM was founded in 1909 as an ethnographic museum. Its focus was on collecting, researching, preserving and exhibiting the artefacts of Estonia's fading peasant culture. Today the museum engages with traditional as well as contemporary life, and with tangible and intangible cultural heritage. The ENM is a centre for essentially ethnological but increasingly multidisciplinary research, and the mediator of diverse ideas and values that mixes traditional methods with innovative approaches in scientific research as well as exhibition making. 
Figure 1: Estonian National Museum. Project by DGT Architects.

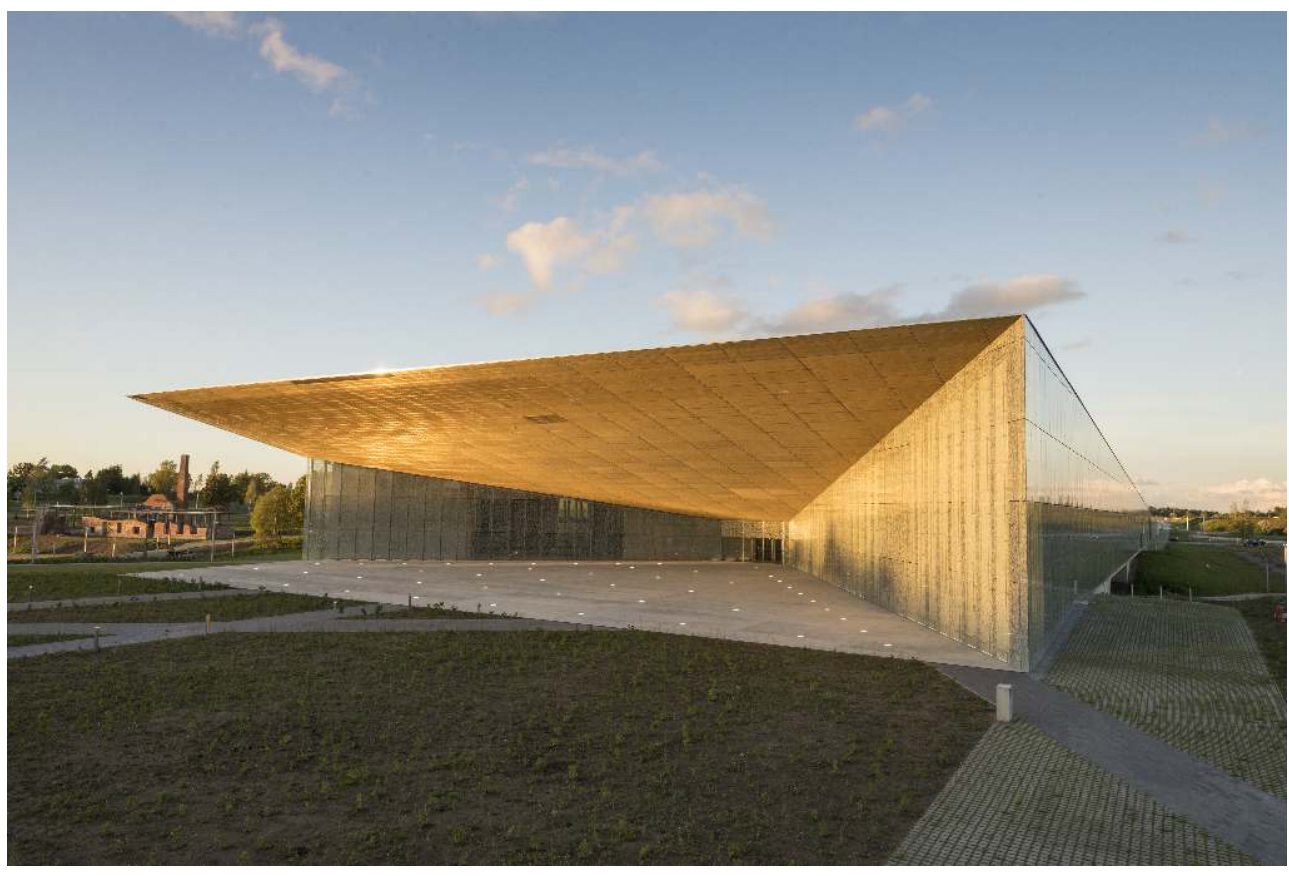

DGT Architects (2016): "With a sensitive implementation on this site, the National Museum becomes a continuation of the airfield - its roof lifting and expanding towards 'infinite space' - inviting the visitor to enter into the landscape and into the heart of the museum. DGT's design creates an open house for public activities - exhibition, performance, learning - a place of gathering and interaction, bringing people together to celebrate a rich, if sometimes painful, history" (Internet Source 1).

Photo by Arp Karm.

The name of the permanent exhibition about Estonian life and culture is Encounters. There are a number of subsections that among other topics focus on independence, life during Soviet occupation, domestic life, language, food and environment. The exhibition expresses the overall idea of the importance of dialogues that the museum wishes to create and encourage. A dialogue between the visitor and exhibitions, a dialogue between the present and the past, and a dialogue between the people and the museum is essential. However, most importantly, a dialogue in today's society is aimed to be encouraged.

4 Traditionally an object-based museum, the ENM has integrated numerous contemporary approaches in the new permanent exhibition. An immediately noticeable feature is the substantial number of screens in the exhibition space. Although the use of films is not novel in museum exhibitions, the purposes for using this medium have broadened and films are no longer only used as illustrations or auxiliary material to support the understanding of the exhibited objects. Films in Encounters aim to represent topics that an object cannot always effectively communicate, often because of the complexity of people's cognitive worlds.

5 The aim of this paper is to analyse the ways in which films in Encounters explore and convey life experiences and support the concept of dialogue-creating. The paper describes the content, style and methods of the films that were produced for Encounters. I explore approaches in common for documentaries and reenactment films in a museum setting. 


\section{From Stories of Freedom to Stories of Consumption: Films Produced for Encounters}

6 Film in various forms holds a solid position in Encounters. Most of the audiovisual material was specially produced for this exhibition and is curated by museum professionals and film production team Allfilm. The documentary content was created with the contribution of various contemporary people living in Estonia, and the fictional or reenacted films are largely based on historical documents. ${ }^{2}$

7 The films alone do not provide the visitors direct means for a two-way communication; however, they are not hidden behind a wall, neither muffled with headphones, but instead have a clear relationship with the surrounding exhibits and interactive screens, a number of which are developed to invite the visitors to create content for the museum. ${ }^{3}$

8 The concept of dialogue in the films does not necessarily emerge as a verbal interaction between two parties. Instead, the dialogical features in Encounters are mostly to be seen in the juxtaposition of different views (Rattus 2016a: 160). Enabling the visitors to interpret the material potentially motivates them to become active participants who give personal meaning to the themes presented in the films.

9 The main author of the films is Estonian filmmaker Marko Raat. He divides his exhibition films into two broad categories - processes and portraits. Process films are mainly observational documentaries and portrait films are scripted reenactments carried out by professional actors. Raat's main questions concerned how to present often invisible and ordinary personal stories in a way that those support and complement each other (Raat 2017). Besides Raat's films, I will be analysing my own video exhibit, titled Stories of Freedom that mainly deals with immaterial topics. It is a cumulative account about freedom - an abstract but intrinsically human concept that is represented by seventyfour 2-4 minute video interviews conducted with contemporary habitants of Estonia.

\section{Stories of Freedom}

10 I started working at the ENM in 2014. It was two years before the opening of the new building and every person in the museum as well as hundreds of project-based employees were working on producing the new permanent exhibitions. ${ }^{4}$ I started a visual research project about how people perceive freedom, be it in a personal, philosophical or social sense. I ended up conducting 74 filmed interviews with Estonian people of varied social, cultural and age groups. The outcome of these interviews is exhibited as a combination of video portraits and projected citations called Stories of Freedom.

This media file cannot be displayed. Please refer to the online document http:// journals.openedition.org/anthrovision/3390

Video link: https://vimeo.com/251318348

12 The interview questions were loosely structured and interviewees could choose their own focus and ways of talking about freedom. Freedom is an abstract concept with which everyone has a personal relationship. There are some freedom narratives that most Estonians relate to - stories of war, deportations, occupations and independence. There 
are also very personal stories of freedom, as well as philosophies of freedom that people follow. The idea of Stories of Freedom was to give a voice to a number of contemporary people and thus give museum visitors a chance to relate to or debate with the ideas presented to them. The written introduction of Stories of Freedom is inspired by what the interviewees revealed to me. It reads:

Freedom is regarded, among other things, as equality, material independence, privacy, an opportunity to vote, to speak, to decide for yourself, and the right to be different. The lack of freedom is associated with illnesses, crime, loneliness, work, addictions, regulations and limitations. Some people think that we are free as long as our thoughts are free, but others believe that there is no such thing as complete freedom. Some may have been able to experience a pure ecstasy of freedom in Siberian prison camp; for others, contemporary Estonian society suppresses and limits their freedom. For some, freedom is gained by learning to know the word of God in their early childhood, whereas for others, religion takes away the liberty to make decisions about their own lives. Some believe that people from different races or sexual orientations may live next to each other in a free country; others see it as taking away their opportunity to feel free. If some see consumption, study and work as liberties, others take them, on the contrary, as constraints (Leivategija 2016).

Stories of Freedom explores how contemporary Estonian inhabitants give sense to historical events often related to traumas of war, deportations and Soviet occupation. In addition, there are plenty of optimistic and idealistic ideas about freedom, but mostly, the exhibit is engaging with social issues about the contemporary society. Many topics that it deals with are complex and might raise disagreement among the museum visitors. As I highlighted in the exhibit introduction above, oppositions can occur when people talk about immigration, religion, LGBT issues, consumer society etc. To give an example, there are two interviewees placing the issue of multiculturalism in the context of their personal freedom, expressing their diametrically opposing perspectives:

Jaano: I ... I am not a racist, but I do find that our tiny nation is such that we should care and protect it a bit more. Multiculturalism, for example, is something that I would not want for my people. This is a bit more complicated for me. I find that we already have those 'grey passport' holders 5 ... to me, they're all immigrants. We already have enough on our hands. This is, yeah, an example of the kind of freedom that I wouldn't want. Not for merely personal reasons, but in a more general sense I hope that the Estonian nation could be a bit more protected from it (Stories of Freedom, Leivategija 2016).

Maari: I do not reside in Estonia and partly that's because I prefer to see more differences around me. Diversity. Here, the street scene is rather homogenous. A single mentality, a single language, a single colour, a single ... everything is singular. This is a bit ... I mean, this really is problematic for me. And I prefer to see a bit more of variation. It gets a kind of tight when one is confined to a single narrow corridor, which one has to follow (Stories of Freedom, Leivategija 2016).

William Isaacs (1999: 19) defines dialogue as a "conversation with a centre, not sides." It can be questionable whether the mentioned contrasting views can actually come together in the centre, but I believe that when every view that is conveyed in Stories of Freedom is constructive and structured, it is possible for the museum visitor to hold a discussion with those ideas, whether she/he agrees with those or not. There are many ideas that visitors might personally disagree with, but those still give hints of the deeper stimulus for the interviewees having those ideas. As long as these are not aggressive, the elucidation of personal views offers us a stimulus to come together in the centre and ideally start a dialogue. "The intention of dialogue is to reach new understanding and, in doing so, to form a totally new basis from which to think and act" (Isaacs 1999: 19). 
Structured and dispassionate dialogues aim to be in the centre of Encounters and should ideally be the same in the society in general.

The portraits of Stories of Freedom (135 minutes) are projected in loop on a massive screen made of concrete. In addition, there are concrete seats in front of the screen onto which short anonymous citations from the interviews are projected in random order. They change occasionally and work essentially as eye catchers to draw visitor's attention and interest towards the screen. The citations, as well as video portraits have English and Russian translations.

Figure 2: Exhibition film Stories of Freedom.

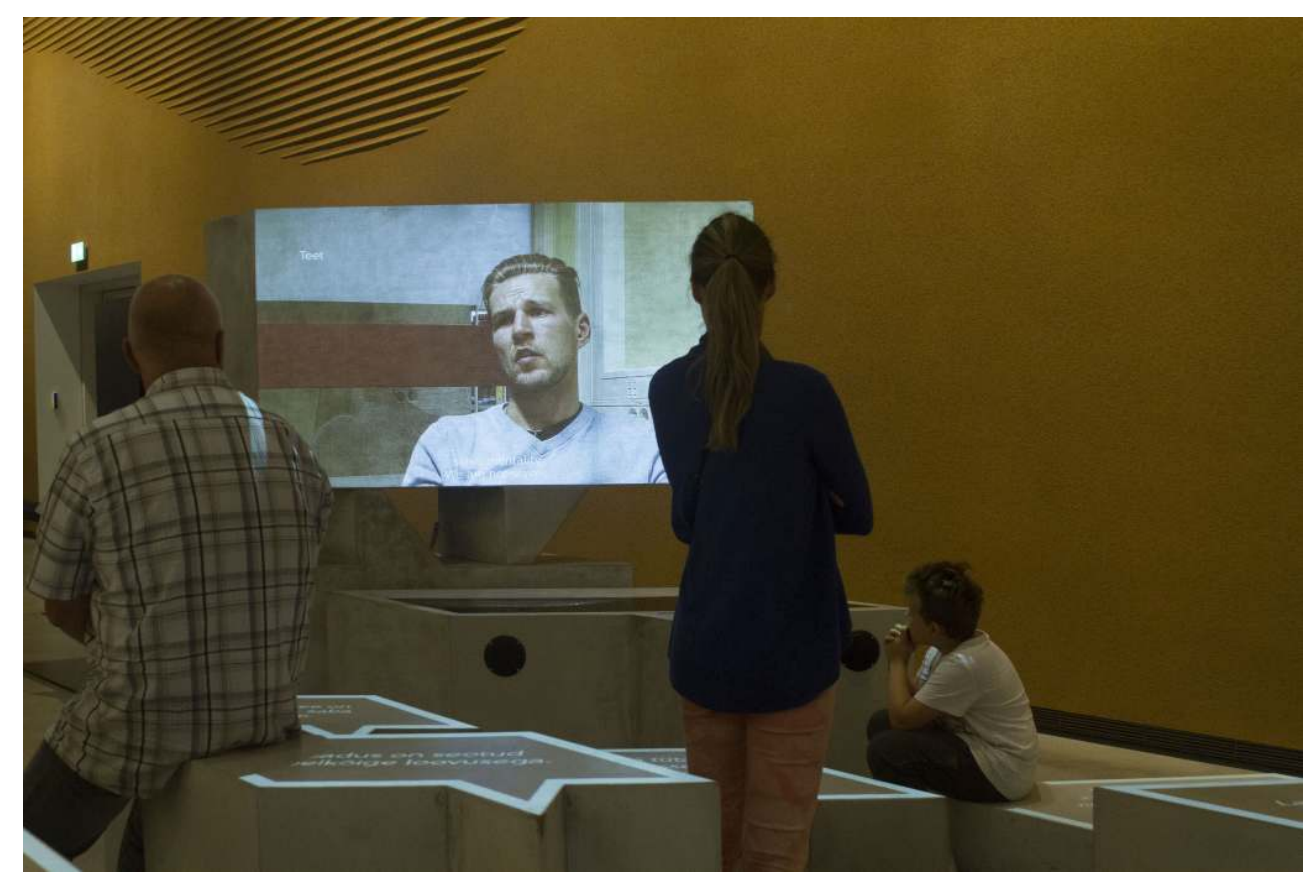

Photo by Tõnn Adermann.

16 These citations together with video interviews have a potential to bring out new layers and points of discussion to the conversations about freedom, as differing ideas expressed simultaneously start to have a dialogue with each other. For example, a citation appears on one of the seats that reads "The fact that I don't sense any limits to my freedom shows my privileged situation in society" (Leivategija 2016). By chance, it could be projected simultaneously with the video portrait of a same-sex couple where one interviewee, Aili, is saying:

The main thing about freedom is that you can be yourself without having any fear. /.../ I think that people who do not have this kind of confrontation with society often do not even perceive that they actually have this freedom to be themselves and identify themselves as they want to (Stories of Freedom, Leivategija 2016).

This combination of ideas is a fleeting and aleatory dialogue that addresses contemporary issues like privilege, equality, and identity among other things. It also creates knowledge and understanding through the ideas that are presented by people with similar worldviews but unequal status in society.

Both examples of dialogues presented above - either opposing or supporting each other are combinations that might not emerge before the visitor. Maari's and Jaano's interviews 
do not follow each other - there are a number of other video interviews between them. Aili's interview and the anonymous citation might not be shown at the same time because the video and projected citations loops are unbound. The possibilities of combinations of dialogues are almost limitless, as there are around 100 citations and 80 interview clips shown in Stories of Freedom. It is like a kaleidoscope of stories with endless combinations of possible messages communicated. The dialogues that take place between interviews, or interviews and citations, are transient and the meanings they create also depend on the visitors' own readiness to find them. But if they do emerge, the dialogue extends beyond the digital space and becomes an interaction between the portrait and the visitor. Conceptually, this exhibit could convey deeper meanings, ideas and wider understanding in and of Estonian society.

\section{Portraits and Processes: The Films of Marko Raat}

Marko Raat's films - the processes and portraits - were in the making for seven years. His collaboration with the ENM's curators, researchers and collections managers resulted in a variety of films. As Encounters in whole, Raat's films do not depict magnificent events and spectacular heroes. Instead, these focus on everyday life, cultural practices and historical events through ages. ${ }^{6}$

An intriguing example of Raat's process films is Checkout Counter Belt, which is a 13-hour observation of the products placed on a supermarket counter belt by ordinary shoppers. Except for occasional glimpses of hands, all we see are the products slowly moving along the mechanical line. It is difficult to engage at first, perhaps because of the ordinariness of what we see, but the more time one takes to inspect the combination of products purchased, the more peculiar the emotion. As Raat (2017) states,

Watching the movement of the mechanical belt is an interesting and emotional experience. If you concentrate on it, there is a human being with their choices and dreams. Every basket of food activates a fantasy about those behind the products. And, if you stay longer to watch, it becomes scary. All those people who have alienated from real food; unhealthy plastic, litres of beer, vodka, lemonade, and sad Kinder Surprises.

There are hundreds of stories moving along that tape that visitors can relate to or respond to. Checkout Counter Belt, like other films and exhibits in Encounters, is not a school lesson based on facts and figures, but rather a potential for discovery, a chance to encounter difference as well as similarity. People's consumption choices are intimate, stimulating for fantasy and speak of the contemporary society. Even though we can observe those choices in any store or supermarket, the massive scale 13-hour film in Encounters exposes society's consumption patterns in a more distinguished form. 
Figure 3: Exhibition film Checkout Counter Belt.

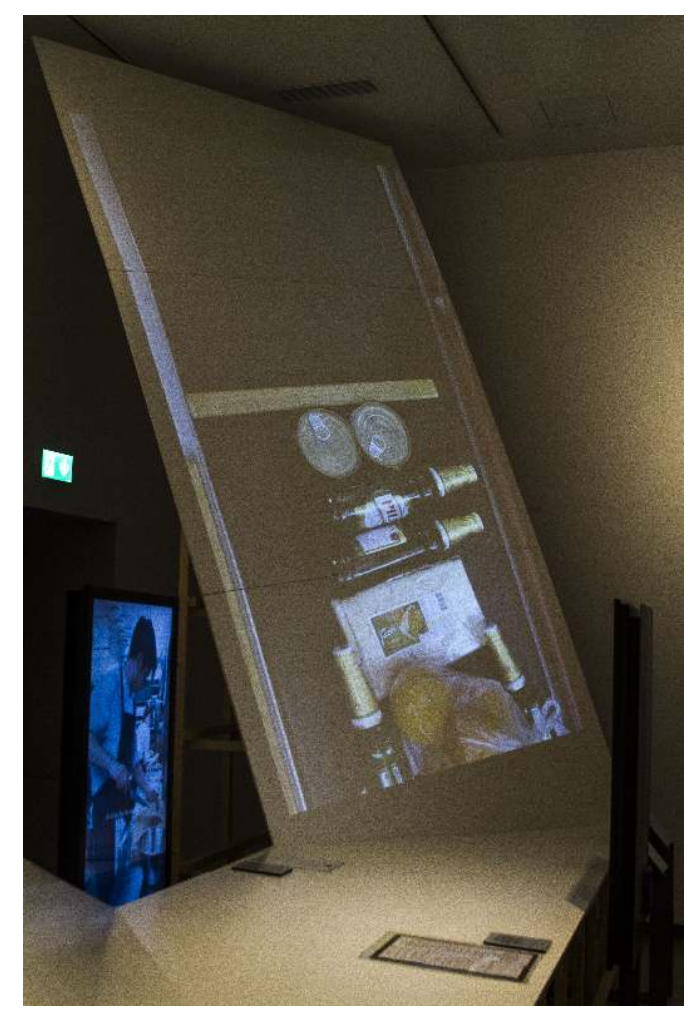

Photo by Tõnn Adermann.

Another process film, which is unconventionally long, serves somewhat different purposes. The 6-hour film Touchstone of Patience is an experiment carried out by nine participants to demonstrate the amount of time and effort it must have taken for the people of the Stone Age to drill a hole in a stone in order to make an axe. When one driller gets tired the next one replaces him/her, but hours later, the hole barely appears to be deeper. The film aims to give museum visitors a sense of how people used to live in a time of which we have no written records. It offers hints of what those temporally faraway people routinely sustained.

This media file cannot be displayed. Please refer to the online document http:// journals.openedition.org/anthrovision/3390

Video link: https://vimeo.com/251318376

Raat (2017) also mentions another interesting layer in the film: "It is intriguing to observe the participants as contemporary people. They are focused and devoted. The longer they take part of this dull process, the more personalised are their portraits, the masks weary and the beauty of focusing is what remains".

To get a better sense of Estonian national costumes, the film Clothing is displayed next to the mannequins wearing traditional costumes. Clothing depicts Roosi, a contemporary elderly woman from the island of Kihnu, who we see dressing up in the traditional Kihnu costume. She describes the process in detail and tells stories about customs of the time when she was young. ${ }^{7}$ This film is a detailed look into a small, but traditionally significant cultural and social activity. 
This media file cannot be displayed. Please refer to the online document http:// journals.openedition.org/anthrovision/3390

Video link: https://vimeo.com/251321468

A number of process films are about manual practices that somewhat still exist today, but are generally associated with traditional rural life or differ from contemporary techniques, like bread-making and beer-brewing. While the ENM has a distinguished audiovisual archive of ethnographic documentaries produced since the 1960s that show traditional cultural practices, Raat and the curators decided not to make use of them in Encounters. This decision was made to underline that the activities in process films are still practised today. The objects placed near the screens originate from the traditional peasant culture and are still being used, as can be seen in the films. Exhibiting traditional objects and contemporary films, in this case, demonstrate the continuity within traditional practices. "As long as there are those who still engage in, develop and interpret these technologies, these skills are alive" (Raat 2017).

Like Touchstone of Patience, these process films emphasise the skill and effort those activities require. Different phases of the processes are shared between a number of screens. For example, the screens showing the film Wool depict the shearing of a sheep, washing, drying and processing of the wool and eventually producing yarn from it. Unlike in Clothing, the camera focuses on the activity but not on the subject. There are close-up shots on hands and materials that demonstrate the processes in detail. There is no background knowledge provided about the bearers of those fading practices.

Raat explains that some of the practitioners were accustomed to performing the activity emphatically, dressed in traditional Estonian peasant robes while others were dressed in contemporary clothes: "My wishful thinking and vision tried to leave those costumes and poses out of the frame, if possible, and focus on the hands that truly possessed the skills" (Raat 2018). By focusing on hands, the otherwise eclectic visual became uniform, and it is potentially easier for the museum visitor to engage with the processes. With subjects made anonymous, the films become somewhat abstract, but the detailed look into the practices provides valuable knowledge about skills that are likely to disappear. 
Figure 4: Process films exhibited in multiple screens.

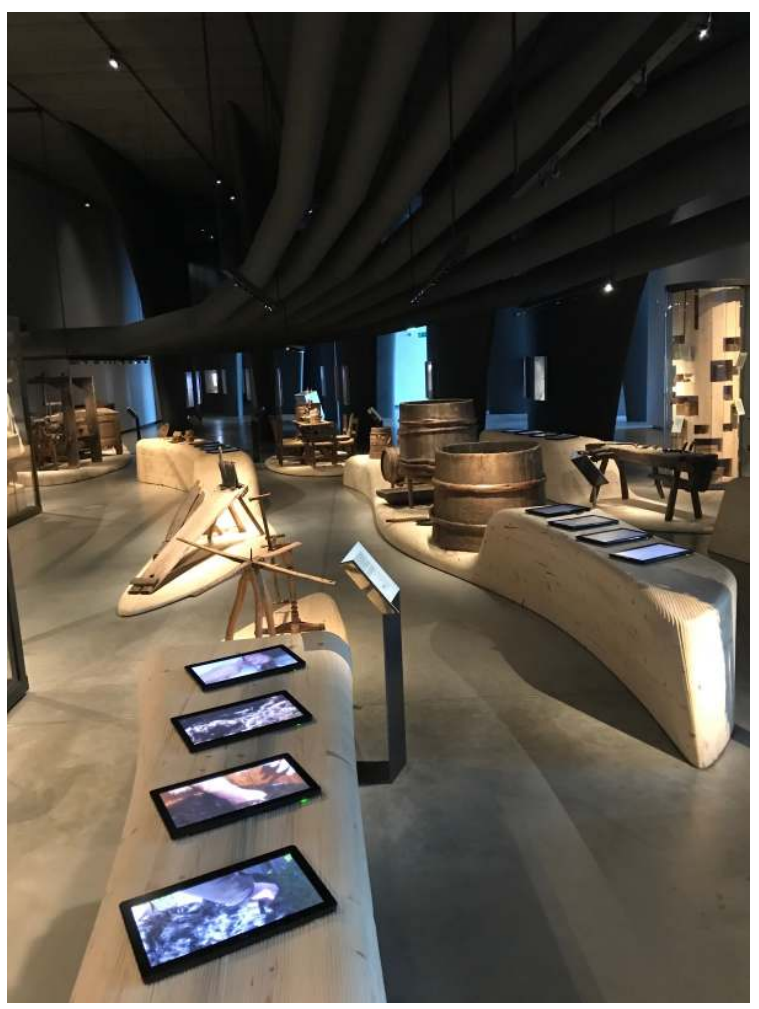

Film Wool in the foreground.

Photo by Karin Leivategija.

Raat's process films employ methods from observational ethnographic film. The shots are long, without voice over and music. There is a lack of apparent drama and the processes are examined in detail. Unlike the process films, the ethnographic approach in the portrait films is somewhat hidden, but on closer inspection it reveals interesting forms. Raat's portrait films are based on archival documents - court trials' documentation, personal letters and memoirs, drawings etc. These films are about the people and events of the past and are reenacted with professional actors and actresses. In the portrait films, the actors are mostly performing monologues to the museum visitors while being engaged in activities related to the film's topic. These films are principally monologues, because the archival documents were written in first person and dialogues in such documents are generally rare. Life in the Factory is based on the recollections of old baize factory workers; 1905 Revolution: Memories presents contrasting perspectives on political unrest in the Russian Empire that Estonia was part of, besides many other depictions of Estonia throughout history.

31 Raat does not have a background in visual anthropology, but he finds similar elements in his reenactment films as in anthropological film. He refuses to dramatize his films artificially: there is no music to direct the audience's feelings, no voice over to inform the audience about how they should perceive the film. The drama of everyday life, the 'action' appears when engaging in the life stories of those people depicted (Raat 2017). In 1905 Revolution: Memories three persons of different ethnic and social background - an Estonian activist, a manor servant and a Baltic German baron - speak about their experiences while the revolution is unfolding. None of them is depicted as the enemy; 
they are humans with their own personal and political agency. As in the process films, the characters in the portrait films are often engaged in activities related to their stories. For example, in Life in the Factory, a girl and a boy talk about working in Sindi baize factory, and simultaneously the detailed process of producing baize unfolds.

This media file cannot be displayed. Please refer to the online document http:// journals.openedition.org/anthrovision/3390

Video link: https://vimeo.com/251318325

The portraits as well as processes are mostly related to objects exhibited near the screen. Many objects used in the films are authentic and belong to the ENM collections. For Raat, the possibility to use them meant endless discussions with the collection managers as these objects are old and potentially fragile. Raat (2017) explains the ideas behind such decision:

The involvement of original museum objects in the films served a number of purposes - to make the museums's biggest asset, the artefacts live again as objects, give them back their context of use in a physical sense, and through such a threat [of damaging the object] become aware of their priceless and unique value.

Although authentic museum objects were employed, the filmmaker applied heavy aesthetic stylization and artificiality, which deliberately revokes implications that the films aim to be precise historical reconstructions of the past. For example, the revolution flag is only seemingly blowing in the wind while the revolutionary pretends to be walking; a bicycle is being ridden but it is not actually moving. It would have been a manipulative attempt to imitate the historical events precisely in terms of visuals. Regarding the depiction of historical events, there are layers of interpretations involved. The individuals document their first-hand subjective experiences, and more than a century later the filmmakers and curators turn the documents into a visual representation of the events. Due to the problematic nature of visualising the past, there cannot be one truthful aesthetic reconstruction. With aesthetic elements explicitly stylized, visitors can understand that the films do not attempt to be precise historical reconstructions (Raat 2017).

This media file cannot be displayed. Please refer to the online document http:// journals.openedition.org/anthrovision/3390

Video link: https://vimeo.com/251318248

Raat's portrait films take a few conscious steps away from being too lifelike, which might otherwise "colonize the audience's historical imagination instead of stimulating and liberating it" (Kaes 1990: 118, cited in Baer 2001: 493). Raat's approach has elements in common with Franz Boas' criticism of life groups exhibited in American Museum of Natural History in the beginning of the 20th century. Boas proposed to keep the artificiality of life groups consciously visible to reduce the risk of creating an illusion of objective truth. As Alison Griffiths (2002: 24) emphasises in Wondrous Difference,

/.../ Boas advocated the use of antirealist conventions that would impart more of a general pedagogic impression than a totalising verisimilitude. Rather than attempt to replicate nature, Boas felt that it was better to underline the synthetic nature of displays. /.../ A fear that the life group's illusionistic spell would numb the minds of museum spectators to pedagogy was replayed in later debates over the possibilities 
of ethnographic motion pictures, as anthropologists feared that motion pictures would similarly privilege spectacle over rational engagement. cultures explored were different from their own, Raat distanced the films from verisimilitude because periods of time shown in portrait films are different from contemporary times. Boas was worried about losing a pedagogical purpose over spectacle, but Raat seems to be sceptical about an overall direct pedagogic effect to be imposed on the audience.

The visual is insistently aesthetized, but simultaneously laconic and eclectic. /.../ There are requisites and gestures consciously used from our contemporary times. All in order to break the illusion of cinematic historical truth (Raat 2017).

These films can generate confusion, which at the same time potentially draws one more into the personal story. The story itself and the person on the screen becomes important, because the visual is clearly far from representing the objective truth. The visitor understands that there is an author behind the films whose reflection is on every stylized and insistently aesthetic element. What was important however was to bring out meaningful details and messages that were found in the source material:

The films based on personal memories have people's attitudes, intellectual values and aspirations on the foreground. The language of these films is insistently aestheticized and stylized, but the bond with the audience is emotional. The characters on screens look straight into the eyes of the visitor. Every long shot is also a mise-en-scène that establishes itself independently (Raat 2017).

Figure 5: Exhibition film 1905 Revolution: Memories.

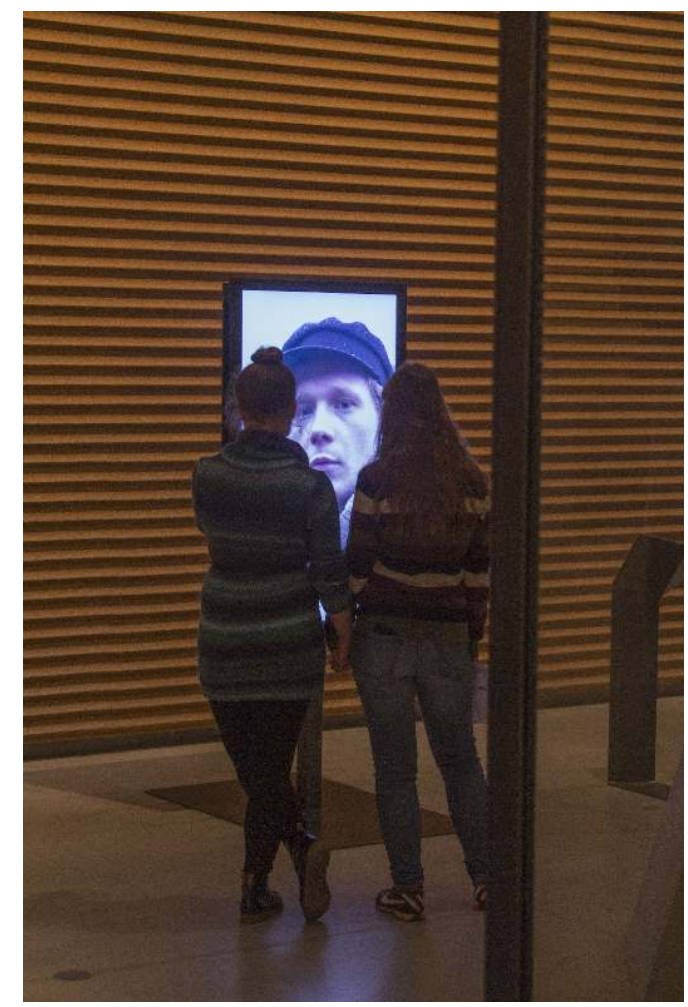

Photo by Tõnn Adermann.

What I find enjoyable in Raat's portrait films, is the meaningful space in the form of silent pauses that the films create between myself and the characters of the films. They gaze at 
me while telling their stories, they often pause to think, look around or grab another bite from their lunch, they walk in silent resistance, eyes fixed on me. There is a space left for me to try and relate to them, many pauses that give me a chance to think about the characters' lives and societies they lived in, and time to reflect on what I have learned. In Stories of Freedom, I left plenty of lengthy pauses uncut for the same reason - the deeper meaning of peoples' ideas on life and freedom can emerge when given time for reflection, for the interviewee as well as the museum visitor.

\section{"It Feels Like One Has to Hurry Somewhere All the Time."}

41 Kristel Rattus, the head curator of Encounters states that it "is definitely not an easy exhibition for visitors. Based on a large amount of visual elements that are to be interpreted intuitively, the exhibition has no one unequivocal interpretation" (2016a: 160). There are multiple identities of peoples who live or have lived in Estonia conveyed through objects, installations, documents, photographs, interactive screens and films. The exhibition sets high expectations for the visitors to delve into it and to take time to watch, listen, read, and eventually question and reflect.

It is common that people often do not have or take that time for themselves. It seems to especially involve watching the films. The ENM is a very big museum and most visitors make an effort to see most of it in a couple of hours. Watching a film that can last more than 10 minutes might evoke restlessness and an urge to move on to the next exhibit. However, this did not unsettle the curators. For Raat and the exhibition team one of the purposes of the films' content and aesthetics was to slow down the overall pace of movement in the exhibition space, so the visitors could focus and be immersed (Raat 2017):

Certainly, people who live in a constantly noisy mediascape automatically find it boring to relate to screens that do not communicate with them in an aggressive manner. All of us, we are spoiled and influenced by the constant noise, so perhaps we do not know at first how to relate to such an introverted screen. However, the purpose was to impose an independent space and time in the exhibition room. A pace that deliberately ignores the constant addiction of audiovisual stimulation and does not exploit the primary desires of the visitor.

Hence, in Raat's films as well as in Stories of Freedom, it is not necessarily the length but the overall slow pace that visitors do not anticipate. The concept of films' form, content and position in the exhibition hall was created so, that even if the visitors stop for only a minute in front of the screens, they still hear and see representations of fragments of lives lived. If they do not stop at all, the voices and visuals from the films steadily accompany them as no film is hidden inside a closed room or is muffled with headphones.

Once, when I was taking photographs of Stories of Freedom, a visitor rushed past towards the entrance and casually stated to her companion: "It is hard to admit to yourself that you are a prisoner of your own way of thinking." She took no notice of the exhibit as a whole, but still picked up the message that she heard being said on the screen. 
Figure 6: A citation from the exhibit Stories of Freedom

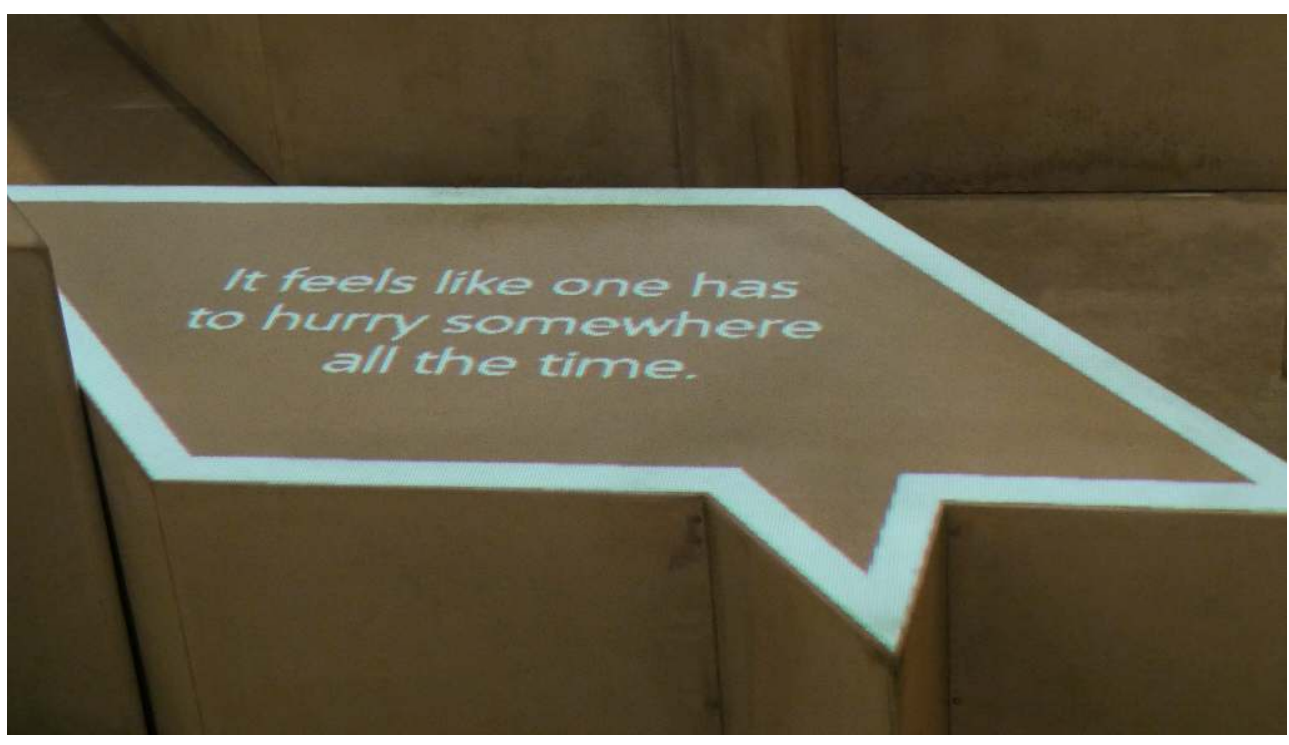

Photo by Karin Leivategija.

\section{Conclusion}

The aim of the films produced for the ENM's permanent exhibition Encounters is to present multiple perspectives and narratives about what it has meant and means to live in Estonia. Sometimes these perspectives contradict each other, but they do so to serve a purpose. They have a potential to create a ground for dialogue in the society, bring about new knowledge and ways of looking at public and personal issues. Film is used as a tool for expressing those sometimes colliding and sometimes collective perspectives of life, ideas and events.

What is equally important, the museum films aim to offer a deeper insight to the objects that are being exhibited next to them. However, in those cases the films should not be seen as merely illustrations. While some museum objects have an ability to speak for themselves, many can appear to be lifeless and mute because they are far removed from their original context of use. The use of film in the exhibition can effectively show that there have been real people and life events stored inside and around those objects. My video exhibit Stories of Freedom explores meanings and ideas that are intangible and abstract but at the same time inherently universal to humans. Marko Raat's documentary films take a detailed look at some processes from traditional as well as contemporary life. These films are observational-style documentations of cultural practices that are still alive today, but inevitably fading. Raat's reenacted portrait films are quotations of the lives of the people from the past. These reenacted films use actors and actresses and have a stylized form, but on a closer look they employ an ethnographic approach - the author is reflexive, there is no imposed drama, and what is left are numerous accounts of lived lives that unfold in Encounters.

The films described in this paper form only a part of those exhibited, neither have I managed to describe all the filmic approaches that were used, but those mentioned are examples, which convey the general aims of Encounters. 
presentation of a diversity of perspectives and a relationship with the surrounding exhibits allow the films in Encounters visibly and audibly join in the discussions that the exhibition aims to evoke. The films form a part of Encounters' visual and inherent identity and invite visitors to be a part of a social and cultural dialogue.

\section{BIBLIOGRAPHY}

\section{Books, articles and correspondance}

Baer, Alejandro. 2001. Consuming History and Memory through Mass Media Products. European Journal of Cultural Studies 4(4): 491-501.

Cameron, Duncan F. 1971. The Museum: A Temple or the Forum. Curator: The Museum Journal. 14 (1): 11-24.

Delgado, Elena. 2009. Museums as Spaces of Negotiations. In Museums as Places for Intercultural Dialogue: Selected Practices from Europe. Simona Bodo, Kirsten Gibbs and Margherita Sani, eds. Pp. 8-9. MAP for ID Group, http://www.ne-mo.org/fileadmin/Dateien/public/service/ Handbook_MAPforID_EN.pdf, (accessed 3 May 2019).

Griffiths, Alison. 2002. Wondrous Difference. Cinema, Anthropology \& Turn-of-the-Century Visual Culture. New York: Columbia University Press.

Isaacs, William. 1999. Dialogue: The Art of Thinking Together. New York: Penguin Random House.

Kaes, Anton. 1990. History and Film: Public Memory in the Age of Electronic Dissemination. History and Memory 2(1): 111-129.

Raat, Marko. 2017. Interview with filmmaker by Leivategija via e-mail. June 13, 2017.

Raat, Marko. 2018. Interview with filmmaker by Leivategija via e-mail. January 31, 2018.

Rattus, Kristel. 2016a. Summary: The Role of Dialogue in Encounters, the New Permanent Exhibition at the Estonian National Museum. In Yearbook of Estonian National Museum 59. Pille Runnel and Agnes Aljas, eds. Pp. 159-160. Tartu: Estonian National Museum.

Rattus, Kristel. 2016b. Dialoogilisus Eesti Rahva Muuseumi püsinäitusel “Kohtumised”. In Yearbook of Estonian National Museum 59. Pille Runnel and Agnes Aljas, eds. Pp. 143-159. Tartu: Estonian National Museum.

\section{Films}

Leivategija, Karin, dir. 2016. Stories of Freedom. Film in Museum Exhibition Encounters. Estonian National Museum (production). 135 min.

Raat, Marko, dir. 2016. 1905 Revolution: Memories. Film in Museum Exhibition Encounters. Allfilm oÜ (production). $33 \mathrm{~min}$.

Raat, Marko, dir. 2016. Checkout Counter Belt. Film in Museum Exhibition Encounters. Allfilm OÜ (production). $825 \mathrm{~min}$.

Raat, Marko, dir. 2016. Clothing. Film in Museum Exhibition Encounters. Allfilm OÜ (production). 28 min. 
Raat, Marko, dir. 2016. Life in the Factory. Film in Museum Exhibition Encounters. Allfilm oÜ (production). $17 \mathrm{~min}$.

Raat, Marko, dir. 2016. Touchstone of Patience. Film in Museum Exhibition Encounters. Allfilm OÜ (production). $340 \mathrm{~min}$.

Raat, Marko, dir. 2016. Wool. Film in Museum Exhibition Encounters. Allfilm OÜ (production). 27 $\min$.

\section{Exhibitions}

Encounters, Estonian permanent exhibition. Authors: Rein Ahas, Agnes Aljas, Terje Anepaio, Arvi Haak, Hando-Laur Habicht, Tiit Hennoste, Jaanika Jaanits, Kristiina Johanson, Tõnno Jonuks, Anu Järs, Ehti Järv, Liisi Jääts, Inna Jürjo, Andreas Kalkun, Anu Kannike, Viire Kobrusepp, Marge Konsa, Mikhel Laar, Karin Leivategija, Lea Leppik, Anti Lillak, Külli Lupkin, Kati Lindström, Riin Magnus, Reet Mark, Marleen Metslaid, Merle Muru, Maarja Olli, Ester Oras, Janika Oras, Liina Paales, Ago Pajur, Reet Piiri, Ulrike Plath, Pille Pruulmann-Vengerfeldt, Aivar Põldvee, Kristjan Raba, Riina Rammo, Kristel Rattus, Vaike Reemann, Riina Reinvelt, Maili Roio, Alar Rosentau, Kristiina Ross, Pille Runnel, Reet Ruusmann, Liina Saarlo, Maido Selgmäe, Villu Soon, Uwe Sperling, Taive Särg, Tõnu Tannberg, Taavi Tatsi, Virve Tuubel, Mari Tõrv, Kadri Tüür, Marko Uibu, Eva-Kaia Vabamäe, Liia Vijand, Ellen Värv and Piret Õunapuu. Tartu: Estonian National Museum, 2016.

Echo of the Urals, Finno-Ugric permanent exhibition. Authors: Madis Arukask, Indrek Jääts, Svetlana Karm, Piret Koosa, Nikolay Kuznetsov and Art Leete. Tartu: Estonian National Museum, 2016.

\section{Internet sources}

Internet Source 1: DGT Architects. Estonian National Museum (Eesti Rahva Muuseum), 2008-2016. On Hayashi - Grossschmidt Arhitektuur webpage, http://hga.ee/estonian-national-museum/ (accessed May 6, 2019).

Internet Source 2: Moore, Rowan. 2017. Estonian National Museum Review - Touching and Revealing. On The Guardian webpage, January 1, 2017, https://www.theguardian.com/ artanddesign/2017/jan/01/estonia-national-museum-review-touching-and-revealing-dgt-dorell (accessed 3 May 2019).

\section{NOTES}

1. The museum territory is laden with cultural historical signifiers. The Soviet military prohibited access to the territory for over 50 years and the premises symbolised the occupation and foreign authoritarian rule, but also the independence regained in 1991. Just next to the new museum building there are the ruins of old Raadi manor, which became the location for the museum in 1922 until it was destroyed in the World War II. Manor houses in Estonia are vivid historical symbols, as these were homes for Baltic Germans who were ruling over Estonian serfs for around 700 years. It is a controversial space, to which the museum has added a new layer of history and meaning.

2. The involvement of general public to the content creation in the ENM has a long history. The collection of ethnographic objects of everyday life that eventually made their way to the ENM began in the $19^{\text {th }}$ century. In 1931, the correspondents' network was founded, that until today collects information about various topics sent out to the correspondents by museum professionals. The collected objects and informants' contribution from the past and 
contemporary times are essential to creating exhibitions in the ENM. To encourage more democratic participation and decision making of the general public, the museum offers exhibition space exclusively for people, groups and organisations who are not involved with work in a museum, but wish to curate and exhibit topics important to them.

3. An important strategy of participation is digital access and digital content creation. Interactive screens allow access to whole databases of photos, documents etc. "This means greater access to visitors and the diminishing of the curator's role as the regulator of access and interpretation" (Rattus 2016b: 154, my translation). Some interactive screens in Encounters also encourage content creation by enabling to add information to databases. For example, visitors can mark their approximate location in the Baltic Way in 1989, called also Chain of Freedom. This was a peaceful political demonstration of two million people across Baltic States Estonia, Latvia, and Lithuania, which were then still considered to be constituent republics of the Soviet Union. And, they can also comment on the content created by other visitors.

4. There are two permanent exhibitions at the ENM - Encounters focuses on Estonia and Echo of the Urals explores Finno-Ugric indigenous peoples.

5. 'Grey passport' is a passport for people with undefined citizenship that is still held by many Russian people who moved to Estonia during Soviet occupation.

6. Similarly, The Guardian's review of the ENM states "The museum could be both triumphalist and sentimental, but it is neither. At their best the displays are touching and revealing rather than heroic" (Moore 2017, Internet Source 2).

7. Kihnu is known for its women who often still wear traditional clothes - a practice that is only common during traditional festivities in the rest of Estonia.

8. The curators who participated in producing these films used their diverse range of contacts for film subjects. The backgrounds and motivation to practice these traditions were different for the subjects - for some these activities were part of ordinary everyday work, but for others it had a more performative aspect to it, which included dressing up in traditional robes for audience, for example. Surely, it would have been interesting to portray these people together with their motivations, as different as they were, but the filmmaker implemented his own concept to present the practices, not people.

\section{ABSTRACTS}

This paper explores the ways in which films and videos are incorporated in the Estonian National Museum's new permanent exhibition Encounters, opened in 2016. Although the use of films in museums is not a novel practice, the methods and purposes have greatly broadened in time. Contemporary ethnographic museums are becoming increasingly collaborative with diverse communities and encouraging of social dialogue. Drawing from my own video exhibit Stories of Freedom, and the exhibition films of professional filmmaker Marko Raat, I aim to describe and analyse the methods that support the concept of dialogue creating in Encounters. I explore how the medium of film is integrated in the exhibitions as a means of communicating human experiences.

Cet article aborde la manière dont les films et les vidéos sont incorporés dans la nouvelle exposition permanente du Musée national estonien intitulée Rencontres. Elle fut inaugurée en 2016. Bien que l'utilisation de films dans les musées ne soit pas une pratique nouvelle, les 
méthodes et les objectifs se sont considérablement élargis avec le temps. Les musées ethnographiques contemporains collaborent de plus en plus avec diverses communautés et encouragent le dialogue social. En m'inspirant de ma propre exposition vidéo Stories of Freedom et des films d'exposition du cinéaste professionnel Marko Raat, je cherche à décrire et à analyser les méthodes qui soutiennent le concept de création de dialogue dans "Rencontres". J'analyse la manière dont le support filmique est intégré dans les expositions comme moyen de communication d'expériences humaines.

En este artículo se exploran las maneras en las que las películas y los vídeos se incorporan a la nueva exposición permanente Encounters (Encuentros) del Museo Nacional de Estonia, inaugurada en 2016. Aunque el uso de películas en los museos no es una práctica nueva, los métodos y los propósitos han aumentado considerablemente a lo largo del tiempo. Los museos etnográficos contemporáneos se están volviendo cada vez más colaborativos con las distintas comunidades e impulsores del diálogo social. A partir de mi propia exposición de vídeos Stories of Freedom (Historias de libertad) y de los documentales para exposiciones del cineasta profesional Marko Raat, quiero describir y analizar los métodos que apuntalan el concepto de creación de diálogos en Encounters (Encuentros). Exploro cómo el medio cinematográfico se integra en las exposiciones como un mecanismo para comunicar experiencias humanas

\section{INDEX}

Palabras claves: museo, documental, diálogos, cine etnográfico

Mots-clés: musée, film, dialogue, cinema ethnographique

Keywords: museum, film, dialogue, ethnographic filmmaking

\section{AUTHOR}

\section{KARIN LEIVATEGIJA}

Estonian National Museum

karin.leivategija@erm.ee

Karin Leivategija is a visual anthropologist, filmmaker and exhibition curator. She has a Master's degree in visual anthropology from The University of Manchester. She has been working as a research assistant at the Estonian National Museum in Tartu, Estonia, since 2014. 